\title{
(.) Cross-country comparison of waterpipe use: OPEN ACCESS nationally representative data from 13 low and
middle-income countries from the Global Adult
Tobacco Survey (GATS)
}

Jeremy Morton, ${ }^{1}$ Yang Song, ${ }^{1}$ Heba Fouad, ${ }^{2}$ Fatimah El Awa, ${ }^{2}$ Randa Abou El Naga, ${ }^{2}$ Luhua Zhao, ${ }^{1}$ Krishna Palipudi, ${ }^{1}$ Samira Asma, ${ }^{1}$ on behalf of the GATS Collaborative Group

${ }^{1}$ Office on Smoking and Health, Centers for Disease Control and Prevention, Atlanta, Georgia, USA ${ }^{2}$ World Health Organization Regional Office for the Eastern Mediterranean, Cairo, Egypt

\section{Correspondence to} Jeremy Morton, Centers for Disease Control and Prevention, 4770 Buford Hwy, Atlanta GA 30341, USA; jmorton@cdc.gov

Received 16 October 2012 Revised 12 April 2013 Accepted 21 April 2013 Published Online First 11 June 2013

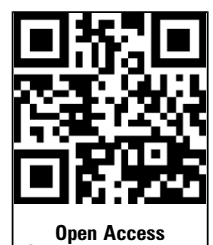
Scan to access m

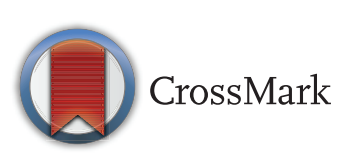

To cite: Morton J, Song Y, Fouad $\mathrm{H}$, et al. Tob Control 2014;23:419-427.

\begin{abstract}
Objective Evidence shows that smoking tobacco using a waterpipe is significantly associated with diseases. Despite this, waterpipe use seems to be increasing worldwide, though nationally representative data are not widely available. The Global Adult Tobacco Survey (GATS) provides an opportunity to measure various indicators of waterpipe use from nationally representative surveys.

Methods Data were obtained for adults 15 years of age or older from 13 countries (Bangladesh, Brazil, China, Egypt, India, Mexico, Philippines, Russia, Thailand, Turkey, Ukraine, Uruguay and Vietnam) who completed GATS from 2008-2010. The GATS questionnaire collected data on current waterpipe use, including daily/less than daily prevalence and number of sessions per day/week. An optional waterpipe module measured former use, age of initiation, and level of consumption during a session.
\end{abstract}

Results GATS was successful in producing nationally representative data on waterpipe use from 13 countries, many of which for the first time. The prevalence of waterpipe use among men was highest in Vietnam (13.0\%) and Egypt (6.2\%); among women, waterpipe use was highest in Russia (3.2\%) and Ukraine (1.1\%). While over $90 \%$ of adults in Ukraine thought smoking tobacco causes serious illness, only $31.4 \%$ thought smoking tobacco using a waterpipe causes serious illness.

Conclusions GATS data provide the ability to analyse waterpipe use within a country and across countries. Monitoring of waterpipe use at a national level will better enable countries to target tobacco control interventions such as education campaigns about the negative health effects of waterpipe use.

\section{INTRODUCTION}

Smoking tobacco using a waterpipe is a centuries-old practice that has been used in the African and Asian regions, but is most commonly associated with the Eastern Mediterranean region. ${ }^{1-3}$

A waterpipe is a device used for smoking tobacco and other substances, and comes in many forms, such as hookahs and bongs (see, eg, figures 1 and 2 ). Bong waterpipes are usually associated with smoking cannabis, and are generally not discussed in research on waterpipe tobacco smoking.
However, there is a long history of using bong waterpipes for smoking tobacco in Asia, starting with the introduction of tobacco smoking in China during the Ming Dynasty (16th century) and subsequent introduction of waterpipe smoking. ${ }^{4}$

Waterpipe tobacco smoking has been primarily associated with adult usage, but recently there has been an emergence of the practice among younger adults and adolescents. ${ }^{5}$ A study conducted at a university in Syria indicated that $62.6 \%$ of men students and $29.8 \%$ of women students reported having ever smoked a waterpipe. ${ }^{6}$ The trend is also spreading to the Western hemisphere where cafes and restaurants are serving waterpipes. In a study at a university in the USA, $48.4 \%$ of students reported having ever used a waterpipe, and $20 \%$ used a waterpipe for tobacco smoking in the past 30 days. ${ }^{7}$ It has been suggested this is due to the sweet flavours of maassel (tobacco soaked in flavoured sugar syrup) which makes it a more pleasant alternative to cigarettes among the younger generation. ${ }^{8}$ When asked why they use waterpipes, common answers include filling up free time and socialising with friends. ${ }^{9} 10$

Many smokers have the misconception that using a waterpipe is less harmful than other ways of using tobacco. ${ }^{11-13}$ They believe it is safer than smoking cigarettes due to the smoke's passage through water which is thought to filter out much of the toxicants. ${ }^{9} 12{ }^{14}$ However, a recent systematic review found that waterpipe tobacco smoking was significantly associated with various diseases. ${ }^{15}$ Toxicants such as polycyclic aromatic hydrocarbons (PAHs), nicotine, tar and particulate matter remain in the inhaled smoke and can pose serious harm to health. ${ }^{16-18}$ Smoking a waterpipe has also been linked to lung cancer, respiratory illnesses, periodontal diseases and low birth weight. ${ }^{15}$ 19-24 Studies have also indicated a possible association between waterpipe usage and infectious diseases, such as tuberculosis, due to the sharing of the mouthpiece during sessions. ${ }^{25}{ }^{26}$ Compared with cigarettes, waterpipe use exposes the smokers and passive smokers to lesser quantities of toxicants in one puff. However, it is not any less harmful due to the depth of each inhaled breath and the duration of each smoking session which usually lasts 45-60 min. ${ }^{2} 27$ In addition, a single waterpipe session can increase blood nicotine and carbon 
Figure 1 Example and diagram of a "hookah" waterpipe.

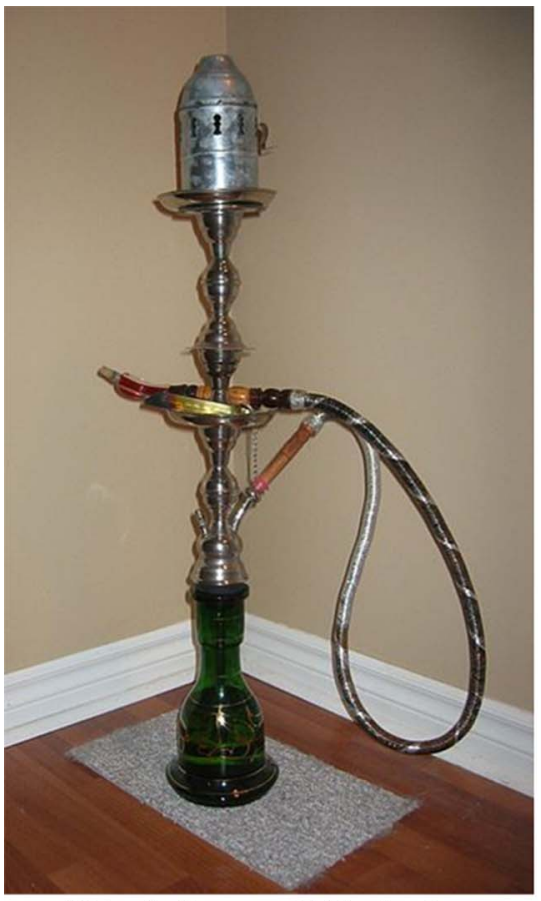

Wikimedia Commons / Public Domain

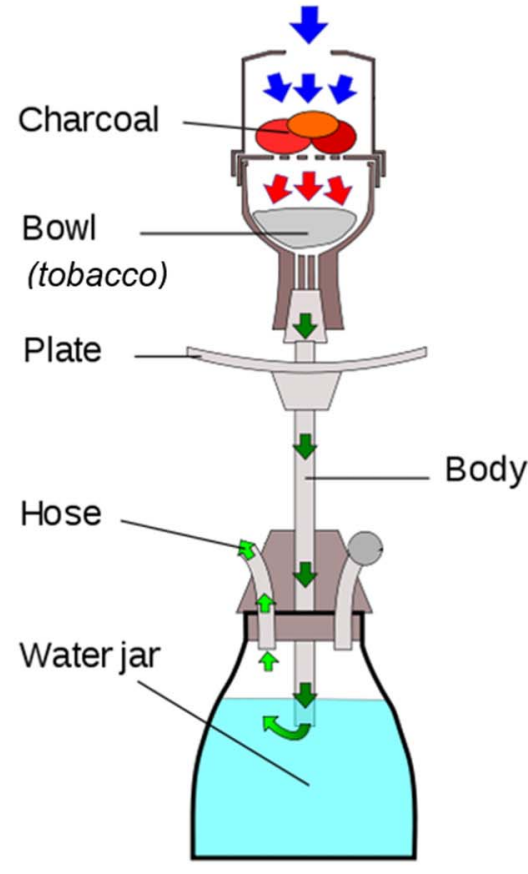

Wikimedia Commons / Public Domain monoxide exposure to higher levels than those observed after a single cigarette. ${ }^{28} 29$

Smoking tobacco using a waterpipe seems to be increasing worldwide $^{30}$ despite the evidence of harmful health effects; though nationally representative data on waterpipe tobacco use are not widely available. A publication in 2011 was believed by the authors to be the "first systematic review of the prevalence of waterpipe smoking and its associated factors across countries, age groups and genders'. ${ }^{31}$ This recent comprehensive search of published data on waterpipe prevalence from scientifically representative studies identified 38 studies. The authors acknowledged that a limitation of their study was that only four of the 38 studies were conducted at national levels. The Global Adult Tobacco Survey (GATS) provides an opportunity to measure the prevalence and characteristics of waterpipe use from nationally representative surveys.

\section{METHODOLOGY}

GATS, a component of the Global Tobacco Surveillance System (GTSS), ${ }^{32}$ was developed to provide a global standard protocol for consistent monitoring of adult tobacco use, and enhance the capacity of countries to design, implement and evaluate tobacco
Figure 2 Example and diagram of a "bong" waterpipe.

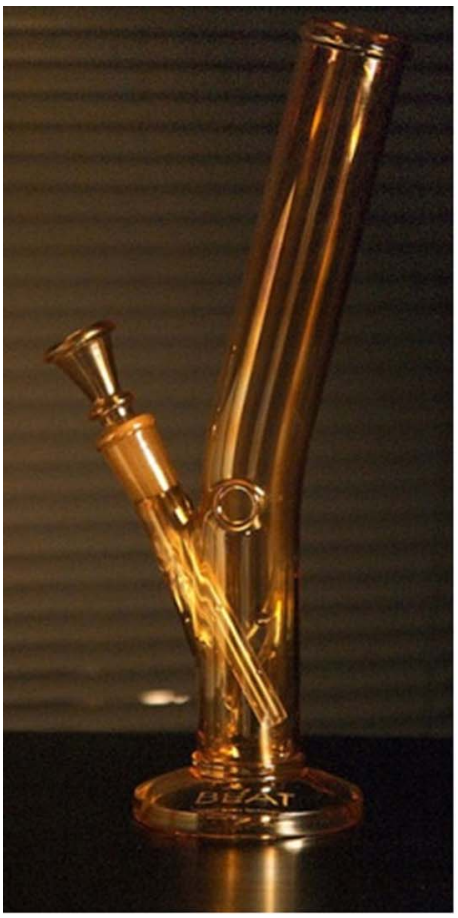

J A Bruinsma / CC-BY-SA-3.0

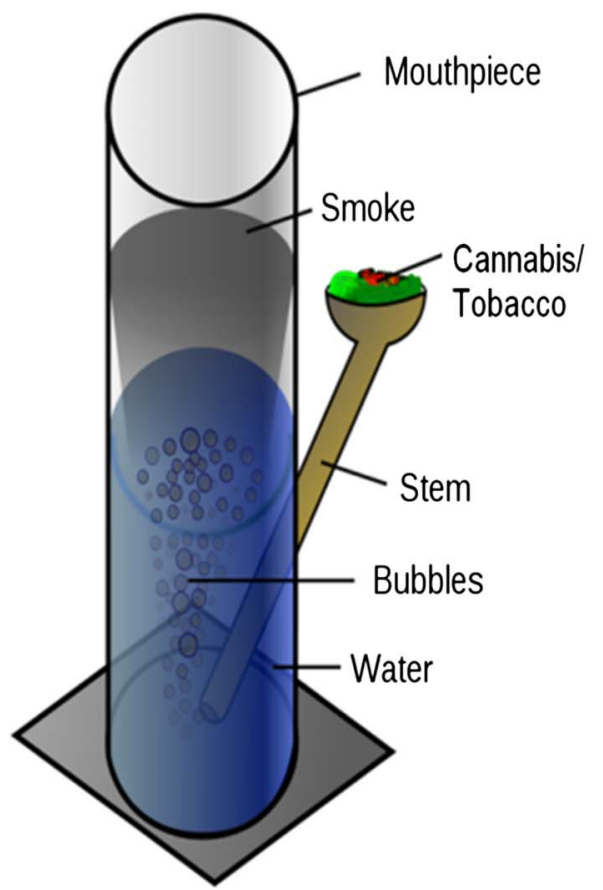

Christopher Thomas / CC-BY-SA-3.0 
Table 1 Prevalence of waterpipe use (\%,95\% Cl) among adults 15 years of age or older, by gender and selected demographic characteristics, GATS 2008-2010

\begin{tabular}{|c|c|c|c|c|c|c|c|c|c|c|c|c|c|}
\hline Demographic & $\begin{array}{l}\text { Bangladesh } \\
(\mathrm{n}=9,629) \\
\text { (Males=4,468) } \\
(\text { Females }=5,161)\end{array}$ & $\begin{array}{l}\text { Brazil }(n=39,425) \\
\text { (Males }=18,039) \\
\text { (Females=21,386) } \\
\end{array}$ & $\begin{array}{l}\text { China } \\
(\mathrm{n}=13,354) \\
\text { (Males=6,603) } \\
\text { (Females=6,751) } \\
\end{array}$ & $\begin{array}{l}\text { Egypt }(\mathrm{n}=20,924) \\
\text { (Males }=10,062) \\
\text { (Females }=10,862) \\
\end{array}$ & $\begin{array}{l}\text { India }(\mathrm{n}=69,296) \\
\text { (Males=33,767) } \\
\text { (Females=35,529) }\end{array}$ & $\begin{array}{l}\text { Mexico } \\
(\mathrm{n}=13,617) \\
\text { (Males=6,160) } \\
\text { (Females=7,457) } \\
\end{array}$ & $\begin{array}{l}\text { Philippines } \\
(\mathrm{n}=9,701) \\
\text { (Males=4,740) } \\
\text { (Females }=4,961)\end{array}$ & 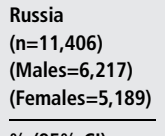 & $\begin{array}{l}\text { Thailand } \\
(n=20,566) \\
(\text { Males }=10,052) \\
\text { (Females }=10,514) \\
\end{array}$ & $\begin{array}{l}\text { Turkey } \\
(\mathrm{n}=9,030) \\
\text { (Males=4,269) } \\
(\text { Females }=4,761) \\
\end{array}$ & $\begin{array}{l}\text { Ukraine } \\
(\mathrm{n}=8,158) \\
(\text { Males }=4,076) \\
(\text { Females }=4,082) \\
\end{array}$ & $\begin{array}{l}\text { Uruguay } \\
(\mathrm{n}=5,581) \\
\text { (Males=2,634) } \\
(\text { Females }=2,947) \\
\end{array}$ & $\begin{array}{l}\text { Vietnam }(n=9,925) \\
\text { (Males }=4,356) \\
\text { (Females }=5,569) \\
\end{array}$ \\
\hline characteristics & & & & & & & & & & & & & \\
\hline Males overall & $1.34(0.86-2.07)$ & $0.18(0.11-0.28)$ & $0.65(0.31-1.36)$ & $6.2(5.59-6.88)$ & $1.13(0.87-1.47)$ & $0.02(0.00-0.08)$ & $0.01(0.00-0.05)$ & $4.44(3.59-5.47)$ & $0.03(0.01-0.08)$ & $3.95(3.04-5.12)$ & $3.17(2.43-4.12)$ & $0.02(0.00-0.10)$ & $13.02(11.36-14.88)$ \\
\hline \multicolumn{14}{|l|}{ Age } \\
\hline $15-17$ & $0.31(0.04-2.21)$ & $0.41(0.13-1.22)$ & $0(-)$ & $0.72(0.20-2.52)$ & $0.01(0.00-0.02)$ & $0(-)$ & $0(-)$ & $1.74(0.57-5.17)$ & $0(-)$ & $1.43(0.36-5.53)$ & $2.8(0.78-9.56)$ & $0(-)$ & $1.14(0.29-4.35)$ \\
\hline $18-24$ & $0.84(0.24-2.83)$ & $0.41(0.21-0.80)$ & $0(-)$ & $2.8(1.78-4.39)$ & $0.37(0.18-0.75)$ & $0(-)$ & $0(-)$ & $\begin{array}{l}10.41(8.09- \\
13.30)\end{array}$ & $0.12(0.04-0.39)$ & $\begin{array}{l}10.78(7.04- \\
16.16)\end{array}$ & $9.42(6.24-13.96)$ & $0(-)$ & $8.02(5.37-11.80)$ \\
\hline $25-39$ & $1.62(1.00-2.61)$ & $0.22(0.10-0.51)$ & $0.48(0.17-1.34)$ & $5.75(4.87-6.79)$ & $0.94(0.65-1.36)$ & $0(-)$ & $0(-)$ & $6.88(5.26-8.96)$ & $0.01(0.00-0.07)$ & $4.14(3.00-5.68)$ & $4.48(3.22-6.22)$ & $0.05(0.01-0.38)$ & $13.92(11.42-16.87)$ \\
\hline $40-54$ & $1.27(0.70-2.28)$ & $0.03(0.00-0.24)$ & $0.91(0.40-2.08)$ & $11.03(9.55-12.70)$ & $1.53(1.09-2.15)$ & $0.04(0.01-0.27)$ & $0(-)$ & $2.4(1.49-3.85)$ & $0(-)$ & $2.24(1.31-3.81)$ & $1.12(0.57-2.19)$ & $0.01(0.00-0.06)$ & $18.12(15.31-21.32)$ \\
\hline $55+$ & $2.09(1.07-4.04)$ & $0(-)$ & $1.16(0.51-2.65)$ & $8.81(7.22-10.71)$ & $2.64(1.86-3.75)$ & $0.07(0.01-0.50)$ & $0.05(0.01-0.33)$ & $0.33(0.06-1.87)$ & $0.04(0.01-0.29)$ & $0.88(0.37-2.04)$ & $0.03(0.00-0.23)$ & $0(-)$ & $14.65(11.87-17.95)$ \\
\hline \multicolumn{14}{|l|}{ Place of residence } \\
\hline Urban & $1.9(1.16-3.10)$ & $0.21(0.13-0.33)$ & $0.18(0.07-0.46)$ & $4.59(3.91-5.38)$ & $0.46(0.33-0.64)$ & $0(-)$ & $0(-)$ & $5.39(4.28-6.76)$ & $0.07(0.03-0.21)$ & $4.94(3.69-6.59)$ & $3.72(2.73-5.05)$ & $0(-)$ & $5.25(4.16-6.61)$ \\
\hline Rural & $1.14(0.60-2.15)$ & $0(-)$ & $1.04(0.45-2.42)$ & $7.54(6.56-8.64)$ & $1.41(1.05-1.90)$ & $0.09(0.02-0.36)$ & $0.01(0.00-0.09)$ & $1.77(1.21-2.60)$ & $0.01(0.00-0.09)$ & $1.67(1.08-2.58)$ & $1.99(1.22-3.23)$ & $0.2(0.03-1.13)$ & $16.36(14.06-18.96)$ \\
\hline \multicolumn{14}{|l|}{ Education } \\
\hline $\begin{array}{l}\text { No formal education/ } \\
\text { Less than primary }\end{array}$ & $1.75(1.05-2.91)$ & ** & $3.43(1.58-7.29)$ & $11.19(9.88-12.66)$ & $1.97(1.49-2.62)$ & $0.07(0.01-0.51)$ & $0(-)$ & $0(-)$ & $0(-)$ & $0.09(0.01-0.63)$ & $\sim$ & $0(-)$ & $12.97(9.74-17.05)$ \\
\hline $\begin{array}{l}\text { Completed primary/ } \\
\text { Less than secondary }\end{array}$ & $0.5(0.27-0.93)$ & ** & $0.87(0.39-1.92)$ & $5.28(3.93-7.07)$ & $1.02(0.67-1.54)$ & $0.03(0.00-0.25)$ & $0(-)$ & $0(-)$ & $0.05(0.01-0.23)$ & $3.08(2.16-4.38)$ & $0(-)$ & $0.04(0.01-0.25)$ & $14.62(11.88-17.87)$ \\
\hline $\begin{array}{l}\text { Completed secondary } \\
\text { or high school }\end{array}$ & $0.82(0.28-2.35)$ & ** & $0.24(0.09-0.66)$ & $3.56(2.94-4.30)$ & $0.42(0.25-0.73)$ & $0(-)$ & $0(-)$ & $3.63(2.80-4.70)$ & $0.05(0.02-0.15)$ & $6.3(4.32-9.11)$ & $2.74(2.03-3.69)$ & $0(-)$ & $13.32(11.40-15.50)$ \\
\hline $\begin{array}{l}\text { Completed college/ } \\
\text { university or above }\end{array}$ & $3.95(1.31-11.32)$ & ** & $0.15(0.02-1.07)$ & $2.62(1.99-3.46)$ & $0.18(0.08-0.39)$ & $0(-)$ & $0.03(0.00-0.22)$ & $6.87(5.18-9.06)$ & $0(-)$ & $3.93(2.15-7.08)$ & $6.01(3.92-9.12)$ & $0(-)$ & $4.59(3.13-6.67)$ \\
\hline Females overall & $0.16(0.05-0.47)$ & $0.1(0.05-0.20)$ & $0.08(0.02-0.40)$ & $0.3(0.16-0.58)$ & $0.64(0.48-0.86)$ & $0(-)$ & $0(0.00-0.02)$ & $3.19(2.36-4.28)$ & $0.01(0.00-0.04)$ & $0.7(0.44-1.10)$ & $1.12(0.74-1.70)$ & $0.13(0.04-0.45)$ & $0.15(0.07-0.29)$ \\
\hline \multicolumn{14}{|l|}{ Age } \\
\hline $15-17$ & $0(-)$ & $0(-)$ & $0(-)$ & $0.31(0.04-2.20)$ & $0.2(0.03-1.41)$ & $0(-)$ & $0(-)$ & $0.84(0.16-4.35)$ & $0(-)$ & $0(-)$ & $2.34(0.32-15.03)$ & $0.29(0.04-2.04)$ & $0(-)$ \\
\hline $18-24$ & $0.04(0.01-0.28)$ & $0.42(0.17-1.00)$ & $0(-)$ & $0.07(0.01-0.52)$ & $0.15(0.06-0.38)$ & $0(-)$ & $0(-)$ & $\begin{array}{l}12.69(8.90- \\
17.79)\end{array}$ & $0(-)$ & $0.87(0.32-2.37)$ & $4.58(2.46-8.39)$ & $0(-)$ & $0(-)$ \\
\hline $25-39$ & $0.09(0.02-0.37)$ & $0.04(0.01-0.14)$ & $0(-)$ & $0.09(0.03-0.26)$ & $0.46(0.29-0.73)$ & $0(-)$ & $0.01(0.00-0.07)$ & $3.33(2.22-4.96)$ & $0.02(0.00-0.12)$ & $1.22(0.73-2.03)$ & $1.15(0.64-2.05)$ & $0(-)$ & $0.21(0.08-0.57)$ \\
\hline $40-54$ & $0.07(0.01-0.50)$ & $0.1(0.03-0.36)$ & $0.14(0.02-1.00)$ & $0.61(0.25-1.45)$ & $0.65(0.44-0.97)$ & $0(-)$ & $0(-)$ & $1.81(0.81-4.00)$ & $0(-)$ & $0.56(0.22-1.41)$ & $0.64(0.24-1.66)$ & $0(-)$ & $0.23(0.07-0.75)$ \\
\hline $55+$ & $0.79(0.23-2.67)$ & $0(-)$ & $0.18(0.04-0.75)$ & $0.71(0.36-1.39)$ & $1.87(1.24-2.81)$ & $0(-)$ & $0(-)$ & $0.5(0.16-1.59)$ & $0(-)$ & $0.04(0.01-0.26)$ & $0(-)$ & $0.33(0.08-1.34)$ & $0.12(0.03-0.50)$ \\
\hline \multicolumn{14}{|l|}{ Place of residence } \\
\hline Urban & $0.03(0.00-0.22)$ & $0.12(0.06-0.23)$ & $0(-)$ & $0.1(0.04-0.23)$ & $0.17(0.07-0.39)$ & $0(-)$ & $0.01(0.00-0.05)$ & $3.93(2.86-5.37)$ & $0.02(0.00-0.11)$ & $0.88(0.53-1.46)$ & $1.56(1.01-2.40)$ & $0.12(0.03-0.49)$ & $0(-)$ \\
\hline Rural & $0.21(0.07-0.64)$ & $0(-)$ & $0.16(0.03-0.74)$ & $0.47(0.22-1.00)$ & $0.83(0.61-1.13)$ & $0(-)$ & $0(-)$ & $0.94(0.57-1.54)$ & $0(-)$ & $0.28(0.13-0.59)$ & $0.19(0.05-0.67)$ & $0.24(0.03-1.71)$ & $0.21(0.11-0.42)$ \\
\hline \multicolumn{14}{|l|}{ Education } \\
\hline $\begin{array}{l}\text { No formal education/ } \\
\text { Less than primary }\end{array}$ & $0.31(0.11-0.92)$ & ** & $0.16(0.04-0.65)$ & $0.63(0.33-1.22)$ & $1.11(0.82-1.49)$ & $0(-)$ & $0(-)$ & $\sim$ & $0(-)$ & $0.03(0.00-0.23)$ & $0(-)$ & $0(-)$ & $0.33(0.15-0.72)$ \\
\hline $\begin{array}{l}\text { Completed primary/ } \\
\text { Less than secondary }\end{array}$ & $0(-)$ & ** & $0.12(0.02-0.83)$ & $0(-)$ & $0.17(0.08-0.38)$ & $0(-)$ & $0(-)$ & $0.37(0.05-2.58)$ & $0(-)$ & $0.36(0.16-0.81)$ & $0(-)$ & $0.13(0.02-0.93)$ & $0.15(0.03-0.64)$ \\
\hline $\begin{array}{l}\text { Completed secondary } \\
\text { or high school }\end{array}$ & $0(-)$ & ** & $0.06(0.01-0.42)$ & $0(-)$ & $0.02(0.01-0.07)$ & $0(-)$ & $0(-)$ & $2.79(1.93-4.01)$ & $0(-)$ & $1.3(0.65-2.60)$ & $1.13(0.65-1.94)$ & $0.18(0.03-0.94)$ & $0.06(0.01-0.41)$ \\
\hline $\begin{array}{l}\text { Completed college/ } \\
\text { university or above }\end{array}$ & $0(-)$ & ** & $0(-)$ & $0(-)$ & $0.01(0.00-0.03)$ & $0(-)$ & $0.01(0.00-0.10)$ & $4.37(2.75-6.89)$ & $0.06(0.01-0.41)$ & $3.8(2.07-6.89)$ & $1.75(0.92-3.33)$ & $0(-)$ & $0(-)$ \\
\hline
\end{tabular}


control interventions. GATS is a nationally representative household survey of adults 15 years of age or older, using a standard core questionnaire, sample design and data collection procedures (face-to-face interview using handheld computers). A series of manuals provide standard requirements on different stages of GATS implementation (available at http://www.cdc.gov/ tobacco/global).

The GATS core questionnaire ${ }^{33}$ includes the following topics on tobacco: Tobacco Smoking, Smokeless Tobacco, Cessation, Secondhand Smoke, Economics-Cigarettes, Media, and Knowledge, Attitudes, and Perceptions. Participating GATS countries adapt the core questionnaire for their own countryspecific situation, and once finalised, the questionnaires are translated into local languages as needed.

The core Tobacco Smoking section collects data on current waterpipe use, including measuring daily or less than daily prevalence, and the number of waterpipe sessions participated in per day (for daily users) or per week (for less than daily users). Current smokers are asked the following question: 'On average, how many waterpipe sessions do you currently participate in per (day/week)?' Current waterpipe smokers include those who smoke a waterpipe daily, and those who smoke a waterpipe less than daily (either on a weekly basis, or less than weekly but within the past 30 days).

Additionally, an optional waterpipe module was developed for countries that wanted to collect additional data on waterpipe use. Questions in the module include measuring former use, age of initiation and various aspects to measure level of consumption during a waterpipe session (eg, session duration, number of people sharing the waterpipe). In a recent review of various waterpipe survey instruments, the authors concluded that the GATS waterpipe module was rigorously developed and was the most comprehensive in measuring the different characteristics of waterpipe use. ${ }^{34}$

Statistical analysis was performed using SPSS V.18.0 for complex samples with $95 \%$ CIs. The data were weighted to represent the population of people 15 years of age or older in each country using a three-step process: (1) calculation of the base weight, (2) non-response adjustment and (3) poststratification calibration adjustment of sample totals to the known population totals. Data were analysed for men and women separately, because of significant gender differences in waterpipe use. Among genders, the primary independent variables used in the analyses were age (five categories), place of residence (urban/ rural) and educational level (four categories).

\section{RESULTS}

Basic waterpipe data from the core questionnaire were available from the following 13 countries that completed GATS from 2008 to 2010: Bangladesh, Brazil, China, Egypt, India, Mexico, Philippines, Russia, Thailand, Turkey, Ukraine, Uruguay and Vietnam. Four of these countries-Egypt, Turkey, Ukraine and Vietnam-included the optional waterpipe module in their questionnaire.

Across the 13 GATS countries, a total of 288800 households were sampled which resulted in the completion of 240612 interviews. The starting sample sizes varied by country, and the number of completed interviews ranged from 5581 (Uruguay) to 69296 (India). Overall response rates ranged from 76.1\% (Ukraine) to $97.7 \%$ (Russia).

\section{Cross-country prevalence}

Table 1 provides the prevalence of current waterpipe smoking (separately for men and women) across the 13 GATS countries, shown by age, urbanicity and education. Among men, the current prevalence of waterpipe smoking was as follows (from highest to lowest): Vietnam (13.0\%), Egypt (6.2\%), Russia (4.4\%), Turkey (4.0\%), Ukraine (3.2\%), Bangladesh (1.3\%), India (1.1\%), China (0.7\%), Brazil $(0.2 \%)$, Thailand $(0.03 \%)$, Mexico (0.02\%), Uruguay (0.02\%) and Philippines (0.01\%).

While a relatively high prevalence of waterpipe smoking was found among the 40-year-old to 54-year-old men in Vietnam (18.1\%) and Egypt (11.0\%), a younger age group of 1824-year-olds had a high prevalence in Russia (10.4\%), Turkey $(10.8 \%)$, and Ukraine (9.4\%). Similar patterns with these countries were found when looking at residence and education. Rural men had a higher prevalence than urban men in Vietnam (5.2\% urban, $16.4 \%$ rural) and Egypt (4.6\% urban, $7.5 \%$ rural); while the opposite was found in Russia $(5.4 \%$ urban, $1.8 \%$ rural), Turkey (4.9\% urban, $1.7 \%$ rural) and Ukraine (3.7\% urban, 2.0\% rural, though not significant).

In Russia and Ukraine, the highest educated men (completed college/university) had the highest prevalence of waterpipe smoking at $6.9 \%$ and $6.0 \%$, respectively. Among the lessereducated men, waterpipe smoking was negligible in Russia and Ukraine and very low in Turkey for those with a less than primary school educational level (0.1\%). By contrast, the lowest educated men in Vietnam and Egypt had the highest prevalence. In Vietnam, the three lower education categories all had a similar prevalence (high school/secondary 13.3\%, less than secondary/primary $14.6 \%$, less than primary 13\%), while in Egypt, the least educated men (less than primary) clearly had the highest prevalence (11.2\%).

Among women, the current prevalence of waterpipe smoking was as follows (from highest to lowest): Russia (3.2\%), Ukraine (1.1\%), Turkey (0.7\%), India (0.6\%), Egypt (0.3\%), Bangladesh $(0.2 \%)$, Vietnam $(0.2 \%)$, Uruguay $(0.1 \%)$, Brazil $(0.1 \%)$, China $(0.1 \%)$, Thailand $(0.01 \%)$, Philippines $(0.0 \%)$ and Mexico $(0.0 \%)$.

When looking at age, residence and education in Russia and Ukraine-the two countries with the highest women prevalence - similar patterns to the men were found. The age group of 18-24 years had a high prevalence in Russia (12.7\%), and in Ukraine, the highest prevalence was found in the age group of 18-24 (4.6\%) years, though not statistically significant. Urban women had a higher prevalence than rural women in Russia (3.9\% urban, $0.9 \%$ rural) and Ukraine (1.6\% urban, $0.2 \%$ rural). The percentages were almost negligible among lower educated women, while the higher educated women had the highest prevalence of waterpipe smoking, though not significant (Russia: high school/secondary $2.8 \%$, college/university or above 4.8\%; Ukraine: high school/secondary 1.1\%, college/university or above $1.8 \%$ ).

\section{Frequency of use}

Table 2 provides the prevalence of daily and less than daily waterpipe smoking, and the average number of waterpipe sessions participated in per week among current waterpipe smokers (both daily and less than daily). This table is restricted to the five countries with the highest male prevalence-

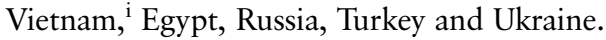

For current waterpipe use among men in the five countries with the highest prevalence, there were more daily waterpipe smokers than less than daily in Vietnam (11\% daily, 2\% less

${ }^{\mathrm{i}}$ Note that data on the number of waterpipe sessions were not available for Vietnam. 
Table 2 Frequency of waterpipe use: prevalence of daily and less than daily use and average number of waterpipe sessions per week among current waterpipe smokers 15 years of age or older, GATS 2008-2010

\begin{tabular}{|c|c|c|c|c|c|}
\hline & $\begin{array}{l}\text { Vietnam } \\
\%(95 \% \mathrm{Cl})\end{array}$ & $\begin{array}{l}\text { Egypt } \\
\%(95 \% \mathrm{Cl})\end{array}$ & $\begin{array}{l}\text { Russia } \\
\%(95 \% \mathrm{Cl})\end{array}$ & $\begin{array}{l}\text { Turkey } \\
\%(95 \% \mathrm{CI})\end{array}$ & $\begin{array}{l}\text { Ukraine } \\
\%(95 \% \mathrm{Cl})\end{array}$ \\
\hline \multicolumn{6}{|l|}{ Males } \\
\hline Overall prevalence & $13.0(11.4-14.9)$ & $6.2(5.6-6.9)$ & $4.4(3.6-5.5)$ & $4.0(3.0-5.1)$ & $3.2(2.4-4.1)$ \\
\hline Daily prevalence & $11.0(9.5-12.7)$ & $5.5(4.9-6.1)$ & $0.8(0.5-1.3)$ & $0.3(0.1-0.9)$ & $1.0(0.6-1.7)$ \\
\hline Less than daily prevalence & $2.0(1.6-2.6)$ & $0.7(0.5-1.0)$ & $3.6(2.8-4.6)$ & $3.6(2.8-4.7)$ & $2.2(1.6-3.0)$ \\
\hline Average number of water pipe sessions per week (mean) & ** & $16.8(14.9-18.6)$ & $3.4(2.3-4.4)$ & $4.5(1.0-7.9)$ & $6.2(4.4-8.1)$ \\
\hline \multicolumn{6}{|l|}{ Females } \\
\hline Overall prevalence & $0.2(0.1-0.3)$ & $0.3(0.2-0.6)$ & $3.2(2.4-4.3)$ & $0.7(0.4-1.1)$ & $1.1(0.7-1.7)$ \\
\hline Daily prevalence & $0.1(0.1-0.2)$ & $0.3(0.1-0.6)$ & $0.3(0.1-0.6)$ & $0.0(0.0-0.1)$ & $0.1(0.1-0.4)$ \\
\hline Less than daily prevalence & $0.0(0.0-0.2)$ & $0.0(0.0-0.1)$ & $2.9(2.1-4.0)$ & $0.7(0.4-1.1)$ & $1.0(0.6-1.6)$ \\
\hline Average number of water pipe sessions per week (mean) & ** & $27.3(16.2-38.4)$ & $2.0(1.4-2.6)$ & $\sim$ & $\sim$ \\
\hline
\end{tabular}

than daily) and Egypt (5.5\% daily, 0.7\% less than daily); while there were more less than daily waterpipe smokers than daily smokers in Russia $(0.8 \%$ daily, 3.6\% less than daily), Turkey (0.3\% daily, $3.6 \%$ less than daily), and Ukraine $(1.0 \%$ daily, $2.2 \%$ less than daily). This pattern was the same for the women in these countries.

The average number of waterpipe sessions participated in per week was clearly the highest in Egypt (men 16.8, women 27.3), followed by Ukraine (men 6.2), Turkey (men 4.5), and Russia (men 3.4, women 2).

\section{GATS waterpipe module}

Four countries-Egypt, Turkey, Ukraine, Vietnam-included the optional GATS Waterpipe Module. Table 3 provides data for three indicators common across these four countries: age of initiation of waterpipe smoking among ever waterpipe smokers, and duration of and number of people sharing the same pipe $\mathrm{i}^{\mathrm{ii}}$ in the last waterpipe session among current waterpipe smokers.

Of men who have ever smoked a waterpipe in Egypt, 75.2\% started smoking waterpipe before the age of 25 years, and $24.8 \%$ started at 25 years of age or above. This finding was also similar for Ukraine (74.7\%) and Vietnam (76.1\%), but different for Turkey where $60.6 \%$ started smoking waterpipe before the age of 25 years.

In Vietnam, 89.6\% of men waterpipe smokers reported their last waterpipe session lasted less than $30 \mathrm{~min}$ and in Egypt, this estimate was $68.8 \%$. Men waterpipe smokers in Turkey had longer sessions as $41.9 \%$ reported their last session lasted $60 \mathrm{~min}$ or more, which was the highest percentage of the four countries in this category.

In Egypt, $80.3 \%$ of men waterpipe smokers reported not sharing the waterpipe instrument in their last session which is in contrast with the other countries. In Vietnam, 46.4\% did not share the instrument, $34.1 \%$ smoked the instrument with one or two others, and almost $20 \%$ smoked the instrument with three or more others. In Ukraine, only $2.5 \%$ did not share the instrument, while almost $53 \%$ smoked the instrument with one or two others, and $44.5 \%$ smoked the instrument with three or more others.

ii Note that data on the number of people sharing the same pipe were not available for Turkey.

\section{Knowledge/perceptions of health effects}

The GATS core questionnaire includes the following question: 'Based on what you know or believe, does smoking tobacco cause serious illness?' Egypt and Ukraine included an additional question asking if the respondents thought that smoking waterpipe causes serious illness.

Overwhelmingly, most respondents thought smoking tobacco causes serious illness (97.6\% in Egypt and 93.2\% in Ukraine) with little to no variation of the results by smoking status and various demographic characteristics. In examining the results of the specific question about smoking waterpipe, Table 4 shows similar findings for Egypt but a vastly different picture for Ukraine.

In Egypt, 97.4\% thought smoking waterpipe causes serious illness and there were almost no variations among any of the subgroups.

In Ukraine, only $31.4 \%$ thought smoking waterpipe causes serious illness, $11.2 \%$ thought it did not, and $57.4 \%$ said they did not know. A higher percentage of non-smokers (34.0\%) thought waterpipe smoking causes serious illness than current smokers (24.9\%). Differences were also found for place of residence (urban 33.5\%, rural 26.8\%) and education, as the most educated (college/university or above) had the highest percentage of those reporting smoking waterpipe causes serious illness $(40.8 \%)$. The lower educated groups clearly were unaware whether waterpipe smoking was harmful as almost $80 \%$ answered. 'Don't know' to this question.

\section{DISCUSSION}

While there is a general belief that waterpipe smoking is increasing worldwide, the lack of published nationally representative studies on waterpipe smoking makes it difficult to use the GATS data presented in this paper as evidence towards this claim. The GATS nationally representative data do provide an opportunity to examine waterpipe prevalence and various indicators on a cross-country level.

Waterpipe smoking is commonly associated with the Eastern Mediterranean region. ${ }^{1-3}$ However, out of the 13 GATS countries that produced national estimates on waterpipe smoking, the highest prevalence for men was found in Vietnam. This finding should not be surprising given that past research in Vietnam ${ }^{35}$ has shown to be consistent with the current estimate that was obtained in GATS. Similar geographically located countries-Egypt and 
Table 3 Selected analysis indicators from the GATS waterpipe questionnaire module, reported for waterpipe smokers 15 years of age or older in Egypt, Turkey, Ukraine and Vietnam, GATS 2008-2010

\begin{tabular}{|c|c|c|c|c|}
\hline & $\begin{array}{l}\text { Egypt } \\
\%(95 \% \text { CI) }\end{array}$ & $\begin{array}{l}\text { Turkey } \\
\%(95 \% \mathrm{CI})\end{array}$ & $\begin{array}{l}\text { Ukraine } \\
\%(95 \% \mathrm{Cl})\end{array}$ & $\begin{array}{l}\text { Vietnam } \\
\%(95 \% \mathrm{CI})\end{array}$ \\
\hline \multicolumn{5}{|l|}{ Males } \\
\hline \multicolumn{5}{|c|}{ Age at initiation of water pipe smoking ${ }^{1}$} \\
\hline$<18$ years & $30.3(26.6-34.3)$ & $32.3(23.8-42.1)$ & $22.2(14.9-31.9)$ & $33.1(29.2-37.3)$ \\
\hline $18-24$ & $44.9(40.8-49.1)$ & $28.3(21.5-36.4)$ & $52.5(42.6-62.1)$ & $43.0(38.7-47.5)$ \\
\hline 25 and above & $24.8(21.4-28.6)$ & $39.4(31.2-48.2)$ & $25.3(18.2-34.0)$ & $23.9(20.4-27.7)$ \\
\hline \multicolumn{5}{|l|}{ Duration of last session ${ }^{2}$} \\
\hline$<30$ minutes & $68.8(63.8-73.3)$ & $23.8(14.8-35.9)$ & $41.4(29.7-54.3)$ & $89.6(86.5-92.1)$ \\
\hline 30 to 59 minutes & $13.0(9.9-16.9)$ & $34.3(24.5-45.8)$ & $37.6(24.7-52.6)$ & $6.6(4.6-9.3)$ \\
\hline 60 minutes and above & $18.3(14.6-22.7)$ & $41.9(31.2-53.4)$ & $20.9(13.6-30.9)$ & $3.8(2.3-6.2)$ \\
\hline \multicolumn{5}{|c|}{ No. of people sharing the pipe ${ }^{2}$} \\
\hline 0 & $80.3(76.2-83.9)$ & ** & $2.5(0.8-7.8)$ & $46.4(41.3-51.5)$ \\
\hline 1 to 2 & $11.9(9.0-15.4)$ & ** & $53.0(41.5-64.2)$ & $34.1(29.4-39.2)$ \\
\hline 3 or more & $7.8(5.7-10.7)$ & ** & $44.5(33.5-56.1)$ & $19.5(15.6-24.1)$ \\
\hline \multicolumn{5}{|l|}{ Females } \\
\hline \multicolumn{5}{|c|}{ Age at initiation of water pipe smoking ${ }^{1}$} \\
\hline$<18$ years & $38.8(20.2-61.3)$ & $8.8(1.4-38.7)$ & $22.6(12.7-37.0)$ & $\sim$ \\
\hline $18-24$ & $19.5(9.0-37.1)$ & $44.0(25.3-64.5)$ & $46.6(34.0-59.7)$ & $\sim$ \\
\hline 25 and above & $41.8(27.3-57.8)$ & $47.3(31.6-63.5)$ & $30.7(21.8-41.4)$ & $\sim$ \\
\hline \multicolumn{5}{|l|}{ Duration of last session ${ }^{2}$} \\
\hline$<30$ minutes & $72.0(43.4-89.6)$ & $37.6(21.6-57.0)$ & $25.1(12.8-43.4)$ & $\sim$ \\
\hline 30 to 59 minutes & $19.3(6.5-45.0)$ & $44.2(27.1-62.8)$ & $24.0(12.0-42.2)$ & $\sim$ \\
\hline 60 minutes and above & $8.7(1.7-33.6)$ & $18.2(7.8-36.9)$ & $50.9(31.1-70.4)$ & $\sim$ \\
\hline \multicolumn{5}{|c|}{ No. of people sharing the pipe ${ }^{2}$} \\
\hline 0 & $61.4(46.6-74.3)$ & ** & $0(-)$ & $\sim$ \\
\hline 1 to 2 & $29.5(17.8-44.6)$ & ** & $41.1(22.7-62.3)$ & $\sim$ \\
\hline 3 or more & $9.2(2.1-31.9)$ & ** & $58.9(37.7-77.3)$ & $\sim$ \\
\hline
\end{tabular}

Turkey, and Russia and Ukraine-rounded out the top five of highest prevalence of waterpipe smoking among men.

A few patterns emerged when exploring who was smoking waterpipes in the five countries with the highest male prevalence. In Vietnam and Egypt, the men who smoked waterpipes tended to be older (40-54 years old), lived in rural areas, and were less educated. For Egypt, these findings are consistent with previous results; given that waterpipe (shisha) smoking is an old tradition in Egypt. ${ }^{36}$ By contrast, in Russia, Turkey and Ukraine, the men who smoked waterpipe tended to be younger (18-24 years old), lived in urban areas, and were more educated. Current men waterpipe smokers tended to be daily waterpipe smokers in Vietnam and Egypt, while they tended to be less than daily waterpipe smokers in Russia, Turkey and Ukraine. Egyptian men waterpipe smokers clearly smoked the waterpipe more often than men waterpipe smokers in the other four countries.

The optional GATS Waterpipe Module provided additional analysis indicators associated with waterpipe smoking for Egypt, Turkey, Ukraine and Vietnam. Over $60 \%$ of men waterpipe smokers started using a waterpipe before the age of 25 in Egypt, Turkey, Ukraine, and Vietnam. These findings suggest the increase of other tobacco products than cigarettes, especially among younger age groups.

Smoking waterpipe is often described as a social occasion where multiple people participate in sessions of waterpipe smoking, ${ }^{9} 10$ and the GATS results seem to support this notion.
In Vietnam, over half the men waterpipe smokers shared the waterpipe instrument with at least one other person, and in Ukraine, almost all men waterpipe smokers (97.5\%) shared the instrument with at least one other person. In Egypt, while the men waterpipe smokers tended not to share the instrument with others $(80.3 \%)$, this does not necessarily indicate they are smoking alone. Rather, it is presumed they do gather with other waterpipe smokers (eg, at cafes), but tend to smoke their own instrument. In measuring duration of waterpipe sessions, men waterpipe smokers in Turkey tended to have longer waterpipe sessions than the other three countries.

The GATS data from Egypt and Ukraine provide conflicting results toward the notion that people believe waterpipe smoking is not as harmful as smoking cigarettes. In Egypt, over 97\% thought that smoking tobacco and smoking waterpipe causes serious illness. In Ukraine, while 93\% thought that smoking tobacco causes serious illness, only 31\% reported waterpipe smoking causes serious illness and 57\% said they did not know.

\section{CONCLUSION}

The findings in this report are subject to a few limitations. All data were self-reported, and social norms (eg, unacceptability in some countries of women smoking) might have affected responses. Additionally, indicators were not available for some countries, including the number of waterpipe sessions for Vietnam, and the number of people sharing the same waterpipe for Turkey. 
Table 4 Percentage of adults 15 and older in Egypt and Ukraine who believe that smoking waterpipe tobacco causes serious illness, by smoking status and selected demographic characteristics, GATS 2008-2010

\begin{tabular}{|c|c|c|c|c|c|c|}
\hline \multirow[b]{2}{*}{ Demographic characteristics } & \multicolumn{3}{|l|}{ Egypt } & \multicolumn{3}{|l|}{ Ukraine } \\
\hline & $\begin{array}{l}\text { Yes } \\
\%(95 \% \mathrm{Cl})\end{array}$ & $\begin{array}{l}\text { No } \\
\%(95 \% \mathrm{Cl})\end{array}$ & $\begin{array}{l}\text { Don't Know } \\
\%(95 \% \mathrm{Cl})\end{array}$ & $\begin{array}{l}\text { Yes } \\
\%(95 \% \mathrm{Cl})\end{array}$ & $\begin{array}{l}\text { No } \\
\%(95 \% \mathrm{Cl})\end{array}$ & $\begin{array}{l}\text { Don't Know } \\
\%(95 \% \mathrm{Cl})\end{array}$ \\
\hline Overall & $97.4(97.0-97.8)$ & $0.6(0.4-0.9)$ & $2.0(1.7-2.3)$ & $31.4(29.6-33.2)$ & $11.2(10.1-12.5)$ & $57.4(55.4-59.3)$ \\
\hline \multicolumn{7}{|l|}{ Smoking Status } \\
\hline Current smoker & $97.4(96.7-98.0)$ & $1.0(0.6-1.4)$ & $1.6(1.2-2.2)$ & $24.9(22.4-27.5)$ & $17.6(15.3-20.2)$ & $57.5(54.6-60.4)$ \\
\hline Non-smoker & $97.4(97.0-97.8)$ & $0.5(0.3-0.8)$ & $2.1(1.8-2.4)$ & $34.0(32.0-36.1)$ & $8.6(7.6-9.9)$ & $57.3(55.2-59.4)$ \\
\hline \multicolumn{7}{|l|}{ Water Pipe Smoking Status } \\
\hline Current smoker of water pipe & $95.4(92.4-97.3)$ & $2.4(1.1-5.1)$ & $2.2(1.1-4.5)$ & $27.9(19.4-38.3)$ & $51.3(41.0-61.5)$ & $20.8(13.4-31.0)$ \\
\hline Non-smoker of water pipe & $97.5(97.1-97.8)$ & $0.5(0.4-0.8)$ & $2.0(1.7-2.3)$ & $31.5(29.7-33.3)$ & $10.4(9.3-11.6)$ & $58.1(56.2-60.1)$ \\
\hline \multicolumn{7}{|l|}{ Gender } \\
\hline Male & $97.5(96.9-98.0)$ & $0.8(0.5-1.4)$ & $1.6(1.3-2.0)$ & $31.3(29.1-33.5)$ & $13.8(12.3-15.5)$ & $54.9(52.6-57.3)$ \\
\hline Female & $97.3(96.8-97.7)$ & $0.3(0.2-0.5)$ & $2.4(2.0-2.8)$ & $31.5(29.3-33.7)$ & $9.1(7.8-10.6)$ & $59.4(57.1-61.7)$ \\
\hline \multicolumn{7}{|l|}{ Age } \\
\hline $15-17$ & $96.8(94.9-98.0)$ & $0.9(0.3-2.2)$ & $2.4(1.4-3.8)$ & $32.2(24.4-41.2)$ & $22.5(16.0-30.6)$ & $45.3(36.4-54.5)$ \\
\hline $18-24$ & $98.3(97.6-98.8)$ & $0.5(0.2-1.0)$ & $1.3(0.9-1.8)$ & $34.5(29.9-39.4)$ & $27.7(23.4-32.3)$ & $37.8(33.3-42.6)$ \\
\hline $25-39$ & $97.9(97.4-98.3)$ & $0.5(0.3-1.0)$ & $1.6(1.2-2.0)$ & $33.8(31.1-36.6)$ & $13.0(11.1-15.2)$ & $53.2(50.3-56.1)$ \\
\hline $40-54$ & $97.3(96.6-97.8)$ & $0.7(0.4-1.1)$ & $2.1(1.6-2.7)$ & $33.2(30.6-36.0)$ & $7.3(5.9-8.9)$ & $59.5(56.7-62.3)$ \\
\hline $55+$ & $95.3(94.2-96.1)$ & $0.6(0.4-1.0)$ & $4.1(3.3-5.1)$ & $26.4(24.1-28.9)$ & $3.8(3.0-4.7)$ & $69.8(67.2-72.2)$ \\
\hline \multicolumn{7}{|l|}{ Place of residence } \\
\hline Urban & $98.0(97.6-98.4)$ & $0.5(0.3-0.7)$ & $1.5(1.2-1.8)$ & $33.5(31.3-35.8)$ & $13.3(11.7-15.0)$ & $53.2(50.7-55.7)$ \\
\hline Rural & $96.9(96.2-97.4)$ & $0.7(0.4-1.2)$ & $2.4(2.0-2.9)$ & $26.8(24.2-29.6)$ & $7.0(5.7-8.5)$ & $66.2(63.3-69.0)$ \\
\hline \multicolumn{7}{|l|}{ Education } \\
\hline No formal education/Less than primary & $95.8(95.1-96.4)$ & $0.8(0.5-1.2)$ & $3.4(2.9-4.0)$ & $18.5(9.7-32.5)$ & $2.2(0.8-6.2)$ & $79.3(64.9-88.8)$ \\
\hline Completed primary/Less than secondary & $98.0(96.7-98.8)$ & $0.6(0.2-2.0)$ & $1.4(0.8-2.4)$ & $14.9(12.2-18.1)$ & $6.3(4.4-8.9)$ & $78.8(74.9-82.2)$ \\
\hline Completed secondary or high school & $98.6(98.2-99.0)$ & $0.4(0.2-0.7)$ & $1.0(0.7-1.3)$ & $31.0(29.1-33.1)$ & $10.6(9.3-12.0)$ & $58.4(56.2-60.5)$ \\
\hline Completed college/university or above & $98.4(97.5-99.0)$ & $0.6(0.3-1.1)$ & $1.0(0.5-1.8)$ & $40.8(37.7-44.0)$ & $15.4(13.0-18.1)$ & $43.8(40.4-47.2)$ \\
\hline
\end{tabular}


Despite these limitations, GATS was successful in producing nationally representative data on waterpipe use from 13 countries, many of which for the first time. These data provide the ability to analyse waterpipe use within a country as well as a cross-country comparison of waterpipe use.

Waterpipe use seems to be an emerging tobacco product among younger age groups in countries where waterpipe use is not an old tradition (eg, Russia). Also, contrasting with cigarette tobacco smoking, people may be less aware of the harmful effects of waterpipe smoking to health, despite the documented evidence in the research literature.

Because of the emergence and lack of knowledge, successful monitoring of waterpipe use at a national level is imperative to measure the effectiveness of current health policies and programs as well as to plan for future tobacco control interventions for this product. Specifically, tobacco education campaigns and healthcare education should include information about the dangers of waterpipe use, especially since GATS data show that many users are unaware that waterpipe smoking causes serious illness.

While this paper only touches on the basic indicators of waterpipe analysis, there is certainly more in-depth analysis that can be undertaken using GATS data. Maziak et al (2007) states: 'Surveillance and epidemiological studies of tobacco use in different populations should be conducted to assess waterpipe use, monitor trends, study determinants and identify groups most at risk' ${ }^{37}$ As GATS continues to expand, nationally representative waterpipe estimates will be available for additional countries. Additionally, GATS will be repeated in the 13 countries which will provide trend data on waterpipe smoking.

GATS questions measuring waterpipe prevalence are also included in the booklet titled 'Tobacco Questions for Surveys: Key Questions from the Global Adult Tobacco Survey' (or TQS). ${ }^{38}$ The purpose of TQS is to promote global standardisation of tobacco survey questions and analysis indicators.

Using these standard questions from GATS or TQS to measure waterpipe prevalence in national studies (GATS or other multirisk factor surveys) will ultimately provide comprehensive data (including trends) to accurately determine the prevalence and impact of waterpipe smoking. GATS and TQS will assist in providing national comparable country profiles and in understanding waterpipe use patterns for this emerging tobacco product.

\section{What this paper adds}

- Many published articles conclude waterpipe tobacco smoking is increasing worldwide, though most studies only measure a specific subset of the population (eg, university students). We provide unprecedented nationally representative data on waterpipe tobacco smoking from 13 low and middle-income countries.

- The data show that while the overall national prevalence is relatively low for these countries, waterpipe smoking may be increasing for certain subgroups, and in countries not commonly associated with waterpipe use.

- Continued monitoring of waterpipe use at a national level will enable countries to successfully target tobacco control interventions for this emerging tobacco product.

Acknowledgements The authors would like to acknowledge the GATS country surveillance teams; WHO Regional Surveillance Officers; CDC Global Tobacco Control Branch; and the Bloomberg Initiative to Reduce Tobacco Use, a program of Bloomberg Philanthropies, for providing financial support to GATS.
Collaborators On behalf of the GATS Collaborative Group.

Contributors This research was conducted on behalf of the GATS Collaborative Group. Errors, if any, are those of the authors. The findings and conclusions in this report are those of the authors and do not necessarily represent the official position of the Centers for Disease Control and Prevention.

\section{Competing interests None.}

Provenance and peer review Not commissioned; externally peer reviewed.

Data sharing statement All data included in this study are publicly available through the Global Adult Tobacco Survey.

Open Access This is an Open Access article distributed in accordance with the Creative Commons Attribution Non Commercial (CC BY-NC 3.0) license, which permits others to distribute, remix, adapt, build upon this work non-commercially, and license their derivative works on different terms, provided the original work is properly cited and the use is non-commercial. See: http://creativecommons.org/ licenses/by-nc/3.0/

\section{REFERENCES}

1 Rastam S, Ward KD, Eissenberg T, et al. Estimating the beginning of the waterpipe epidemic in Syria. BMC Public Health 2004;4:32.

2 Knishkowy B, Amitai Y. Water-pipe (narghile) smoking: an emerging health risk behavior. Pediatrics 2005;116:113-19.

3 Wolfram RM, Chehne F, Oguogho A, et al. Narghile (water pipe) smoking influences platelet function and (iso-)eicosanoids. Life Sci 2003;74:47-53.

4 Benedict CA. Golden-silk smoke: a history of tobacco in china. Berkeley, CA: University of California Press, 2011.

5 WHO Study Group on Tobacco Product Regulation (TobReg). Advisory Note. Waterpipe tobacco smoking: health effects, research needs and recommended actions by regulators. Geneva, Switzerland: World Health Organization, 2005.

6 Maziak W, Fouad FM, Asfar T, et al. Prevalence and characteristics of Narghile smoking among university students in Syria. Int J Tuberc Lung Dis 2004;8:882-9.

7 Eissenberg T, Ward KD, Smith-Simone $S$, et al. Waterpipe tobacco smoking on a U.S. College campus: prevalence and correlates. J Adolesc Health 2008;42:526-9.

8 Maziak W, Eissenberg T, Rastam S, et al. Beliefs and attitudes related to Narghile (waterpipe) smoking among university students in Syria. Ann Epidemiol 2004:14:646-54.

9 Ward KD, Hammal F, VanderWeg MW, et al. Are waterpipe users interested in quitting? Nicotine Tob Res 2005;7:149-56.

10 Hammal F, Mock J, Ward KD, et al. A pleasure among friends: how narghile (waterpipe) smoking differs from cigarette smoking in Syria. Tob Control 2008:17:e3.

11 Maziak W, Ward KD, Soweid RA Afifi, et al. Tobacco smoking using a waterpipe: a re-emerging strain in a global epidemic. Tob Control 2004;13:327-33. Review.

12 Grekin ER, Ayna D. Argileh use among college students in the United States: an emerging trend. J Stud Alcohol Drugs 2008;69:472-5.

13 Smith SY, Curbow B, Stillman FA. Harm perception of nicotine products in college freshmen. Nicotine Tob Res 2007;9:977-82.

14 Roskin J, Aveyard P. Canadian and English students' beliefs about waterpipe smoking: a qualitative study. BMC Public Health 2009;9.

15 AkI EA, Gaddam S, Gunukula SK, et al. The effects of waterpipe tobacco smoking on health outcomes: a systematic review. Int J Epidemiol 2010;39:834-57. doi:10.1093/ije/ dyq002

16 Sepetdjian E, Shihadeh A, Saliba NA. Measurement of 16 polycyclic aromatic hydrocarbons in narghile waterpipe tobacco smoke. Food Chem Toxicol 2008:46:1582-90.

17 Monzer B, Sepetdjian E, Saliba N, et al. Charcoal emissions as a source of CO and carcinogenic $\mathrm{PAH}$ in mainstream narghile waterpipe smoke. Food Chem Toxicol 2008;46:2991-5

18 Shihadeh A, Saleh R. Polycyclic aromatic hydrocarbons, carbon monoxide, "tar", and nicotine in the mainstream smoke aerosol of the narghile water pipe. Food Chem Toxicol 2005:43:655-61.

19 Nuwayhid IA, Yamout B, Azar G, et al. Narghile (hubble-bubble) smoking, low birth weight, and other pregnancy outcomes. Am J Epidemiol 1998;148:375-83.

20 Tamim H, Yunis KA, Chemaitelly $\mathrm{H}$, et al. Effect of Narghile and cigarette smoking on newborn birthweight. BJOG 2008;115:91-7.

21 Rakower J, Fatal B. Study of Narghile smoking in relation to cancer of the lung. $\mathrm{Br} J$ Cancer 1962;16:1-6

22 El-Hakim IE, Uthman MA. Squamous cell carcinoma and keratoacanthoma of the lower lip associated with "goza" and "shisha" smoking. Int J Dermatol 1999;38 (2):108-10.

23 Al Mutairi SS, Shihab-Eldeen AA, Mojiminiyi OA, et al. Comparative analysis of the effects of hubble-bubble (sheesha) and cigarette smoking on respiratory and metabolic parameters in hubble-bubble and cigarette smokers. Respirology 2006;11:449-55

24 Al-Fayez SF, Ardawi MSM, Zahran FM. Effects of sheesha and cigarette smoking on pulmonary function of Saudi males and females. Trop Geograph Med 1987:40:115-23. 
25 Munckhof WJ, Konstantinos A, Wamsley M, et al. A cluster of tuberculosis associated with use of a marijuana water pipe. Int J Tuberc Lung Dis 2003;7:860-5.

26 Steentoft J, Wittendorf J, Andersen JR. Tuberculosis and water pipes as source of infection. Ugeskr Laeger 2006;168:904-7. Danish.

27 Maziak W, Rastam S, Ibrahim I, et al. CO exposure, puff topography, and subjective effects in waterpipe tobacco smokers. Nicotine Tob Res 2009;11:806-11.

28 Smith-Simone S, Maziak W, Ward KD, et al. Waterpipe tobacco smoking: knowledge, attitudes, beliefs, and behavior in two U.S. samples. Nicotine Tob Res 2008;10:393-8.

29 Cobb C, Shihadeh A, Weaver MF, et al. Waterpipe tobacco smoking and cigarette smoking: a direct comparison of toxicant exposure and subjective effects. Nicotine Tob Res 2011:13:78-87.

30 Cobb C, Ward KD, Maziak W, et al. Waterpipe tobacco smoking: an emerging health crisis in the United States. Am J Health Behav 2010;34:275-85.

31 Akl E, Gunukula SK, Aleem S, et al. The prevalence of waterpipe tobacco smoking among the general and specific populations: a systematic review. BMC Public Health 2011:11:244.
32 The GTSS Collaborative Group. The global tobacco surveillance system. Tob Control 2006;15:ii1-3.

33 Global Adult Tobacco Survey Collaborative Group. Global Adult Tobacco Survey: core questionnaire with optional questions, version 2.0. Atlanta, GA: Centers for Disease Control and Prevention, 2010.

34 Akl E, Aleem S, Gunukula SK, et al. Survey instruments used in clinical and epidemiological research on waterpipe tobacco smoking: a systematic review. BMC Public Health 2010;10:415.

35 Guindon GE. The Impact of Tobacco Prices on Smoking Onset in Vietnam: Duration Analyses of Retrospective Data. Hamilton, Ontario, Canada: Centre for Health Economics and Policy Analysis, McMaster University, 2009.

36 World Health Organization Regional Office for the Eastern Mediterranean. Tobacco Use in Shisha: Studies on Waterpipe Smoking in Egypt. Cairo, Egypt: WHO Regional Office for the Eastern Mediterranean, 2006.

37 Maziak W, Ward KD, Eissenberg T. Interventions for waterpipe smoking cessation. Cochrane Database Syst Rev 2007;(4):CD005549. Review.

38 Global Adult Tobacco Survey Collaborative Group. Tobacco questions for surveys: a subset of key questions from the global adult tobacco survey (GATS), 2nd Edition. Atlanta, GA: Centers for Disease Control and Prevention, 2011. 